\title{
ワゥフラッタメータによるエ作機械主軸の ねじり振動の測定*
}

\author{
山本明** 前田良昭** \\ Measurement of Torsional Vibration of Machine-tools' Spindles by Wow-flutter Meter
}

Akira Yamamoto, Yoshiaki Maeda

In recent years, vibrations of the machine-tool systems have been investigated by many researchers and so many available knowledges have been given. But, about torsional vibrations, only a little investigation has been carried out from luck of the appropriate measuring method. So, for the further experimental analysis of this field, a new measuring method has been developed by the utilization of a marketing wow-flutter meter usually used for the audio recording and reproducing apparatuses. In this paper, the principle and the basic characteristics of this method are discussed and an example of the application, the measurement of the arbor speed variation of the typical small horizontal milling machine, is shown. Main results are as follows:

(1) The developed method not only has a better high frequency response $(\sim 280 \mathrm{~Hz}:-3 \mathrm{~dB})$ in comparison with hitherto reported ones but also can make the measurement comparatively easy and measure even small variations below $0.1 \% \mathrm{p}-\mathrm{p}$ of mean speeds with a good accuracy.

(2) The application shows that even in the racing condition the arbor speed of the tested machine variates with the maximum amplitude of $0.2-0.3 \% \mathrm{p}-\mathrm{p}$ of the mean speed and the dominant frequency components of this variation mostly result from (a) the fluttering of V-belts between the drive motor and the gearbox, (b) the eccentricity of the arbor, (c) the torsional resonance of the driving system and (d) the gear-noises rising in the gearbox. These aspects may be generally applicable to other machines too.

\section{1. 緒言}

旋盤，フライス盤，中ぐり盤の主呻，研削盤の低保軸， など切湖遭動に直接かかわる回転軸系では，たわみ振動 に加えてねじり振動にも注意を要する．近年，工作機械 系の振動問題について多くの検討が進められているが, その対象は才に前者に限られており, 後者に対する検討 は測定上:0問題などから恦めて少ないようである。すな わち、权じり振動の測定は一・般に難しいものと考えられ ており，今までに試みられた種々の方法1)の多くは工作 機械主軸のように比較的小径で馬力の小さいものには適 用困難なことが多く, 忍用されたものも応答周波数帯域

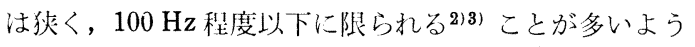
である。

そこで，筆者らは新たに简響機器の回転导ら測走にに朋

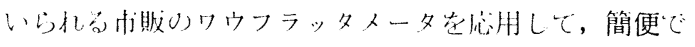

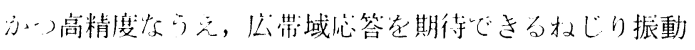
の測定装置を試作し，こ机を䏘い上作機械主軸の水じ

* 原稿受付 昭和 50 年 9 月 11 日. 昭和 49 年度関西地方定 期学術講演会 (昭和 49 年 6 月 6 日) および昭和 50 年度関 西地方定期学術講演会（昭和 50 年 6 月 19 日）にて発表.

** 正会員 大阪大学基礎工学部（豊中市待兼山町 1-1）
り振動を解明与をことを試みた。本報告では，この新し い測症手法（装犆）を紹介し，その特性を検討するとと もに忍用の一例として，フライス盤主軸（アーバ）の空 転時回転むらを測定した結果を示す。

\section{2. 試作装置の測定原理}

\section{1 音響機器における回転むら測定とその応用}

音響機器（テープレコーダ，プレーヤ）の回転速度む ら（ワウフラッタ）の測定に関して，日本工業規格では ワウフラッタメータ（以下 WFM と略記する）を用いる 方法を定めている4). この方法では，単一周波数の基準 信号 $(3 \mathrm{kHz}$ 正弦波) 在記録した試験用標準テープあるい は標準レコードを被検査機器で再生し，この再生信号を WFM で処理して回転むらを測定する。すなわち，再生 速度が変動与れはば, 基準信号注変動信号で周波数変調ざ

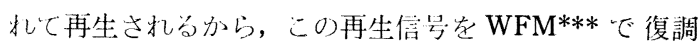
一扎ば变動信号が検出できるのである。

筆者らは，この方法を工作機械三:軸の称じり振動測定 に念用するため, 図 1 に示すように標準信号テープ,レ

\footnotetext{
*** FM 復調回路がその主要部を構成している．その他，一 般に振幅制限回路, メータ指示回路, 聴感補正回路など が組込まれている。
} 


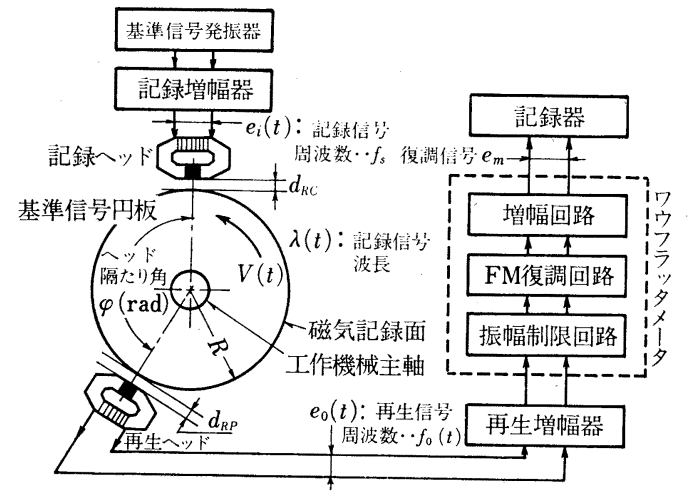

図 1 試作測定系の構成

コードの代わりに磁父信号円板を測定部に取付け，これ に基準信号を記録して用いた。この場合，JISにも規定 されている4)ように基準信号記録時の回転速度は厳しく 一定に保たれねねばならない，本研究では，まず主軸空転 時に基準信号を記録古る方式(空転時記録方式)を試みた が，実測の結果，空転時でもかなり回転速度が変動して おり，この方式では微小变動量の測定に対しては精度上 問題のあることが分かった．これを解決するには，精度 のすぐれた別の記録装置を用意することが望ましいが， 測定の準備などをかなり煩雑にする，そこで，本研究で は測定の簡便性を特に考慮して，次に示す基準信号の記 録と並行して測定它行う方式（同時記録再生方式）によ って,この問題の解決を試夕た.

\section{2 同時記録再生方式による測定}

基準信号 $e_{i}(t)=E_{i} \sin \left(2 \pi f_{s} t\right)$ を半径 $R$ の円板外周部 磁性面に記録し，同時に角度 $\varphi$ だけ隔った再生へッドで この記録信号を再生するとき，軸回転速度（円板周速） $V(t)$ が $V_{0}$ を平均速度, $K_{n}=\Delta V_{n} / V_{0}$ を速度変動率とし $\tau$,

$$
V(t)=V_{0}\left\{1+\sum K_{n} \cdot \sin \left(2 \pi f_{n} t+\alpha_{n}\right)\right\}
$$

のように変動すれば，時刻 $t$ に磁性面に記録される信号 波長 $\lambda(t)$ は

$$
\begin{aligned}
\lambda(t) & =V(t) / f_{s} \\
& =\left(V_{0} / f_{s}\right)\left\{1+\sum K_{n} \cdot \sin \left(2 \pi f_{n} t+\alpha_{n}\right)\right\}
\end{aligned}
$$

となる. いま, 再生信号 $e_{0}$ の周波数 $f_{0}(t)$ に注目して夕 ると，記録された信号法記録時刻から再生おくれ時間 $\Delta t$ を経て再生へッドから再生されるから

$$
\begin{aligned}
f_{0}(t) & =V(t) / \lambda(t-\Delta t) \\
& =\frac{f_{s}\left\{1+\sum K_{n} \cdot \sin \left(2 \pi f_{n} t+\alpha_{n}\right)\right\}}{1+\sum K_{n} \cdot \sin \left(2 \pi f_{n} t+\alpha_{n}-\gamma_{n}\right)}
\end{aligned}
$$

となる.ただし，

$$
\int_{t-\Delta t}^{t} V(t) \mathrm{d} t=R \varphi
$$

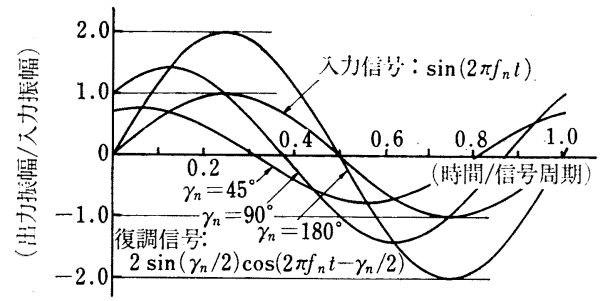

(a)手想される妆力波形

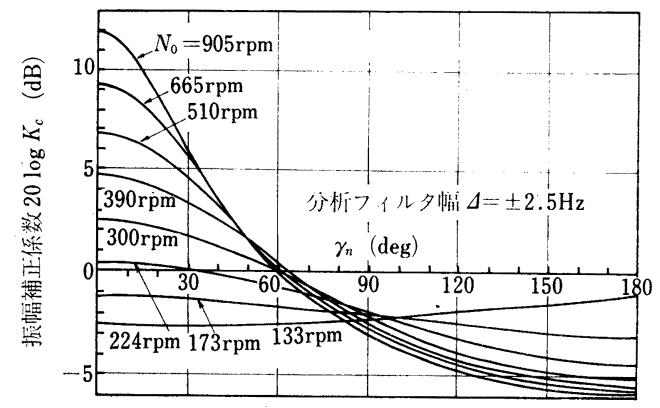

(b) 振幅補正係数

図 2 同時録音再生方式による出力とその補正:

$$
\gamma_{n}=2 \pi f_{n} \Delta t
$$

さらに, 本研究で取扱う範囲では速度変動率 $K_{n}$ は 1 よ り十分小さいので式(3) 注次のように近似できる。

$$
f_{0}(t) \fallingdotseq f_{s}\left\{1+2 \sum K_{n} \cdot \sin \left(\gamma_{n} / 2\right) \cdot \cos \left(2 \pi f_{n} t+\alpha_{n}-\gamma_{n} / 2\right)\right\}
$$

すなわち，この方式では基準信号はカッコ内の第 2 項で 表される信号によって周波数変調されて再生される.こ こで $\Delta t$ は式(4)の関係から $R \varphi / V_{0}$ を中心として $\pm \Sigma$ $\left(K_{n} / f_{n}\right)$ の範囲を变動する量であるから， $\gamma_{n}$ は $n_{0}$ を平均 軸回転数(rps) とすると, $f_{n} \varphi / n_{0}$ を中心として $\pm 2 K_{n}$ の 範囲で変動することになる、いま適当な測定条件を選べ ば，この変動幅を十分に小さくすることができ，式(6) は $\gamma_{n} \fallingdotseq f_{n} \varphi / n_{0}$ として取扱っても，その誤差はほとえど無視 できる*. そこで, 再生信号 $e_{0}$ の FM 復調後の出力波形 は任意の周波数成分 $f_{n}$ に対して，‥般に図 $2(\mathrm{a})$ のよう になると予想さ机る。亦なわち，この方式では復調信号 の振幅は原信号 (变動信号) の $2 \sin \left(\gamma_{n} / 2\right)$ 倍と夜り, 安 た位相も変化与るので，復調信号即変動信号として扱う ことはできないが，補正係数 $K_{c}=\left\{2 \sin \left(\gamma_{n} / 2\right)\right\}^{-1}$ 号用 いて補正すれば容易に速度变動率 $K_{n}$ 足求めることがで きよう.なお，位相量に対しては $\left(\pi / 2-\gamma_{n} / 2\right)$ の進相補 償が必要である. 図 2 (b) に周波数分析時のフィルタ幅 $\Delta$ を考慮した場合の $K_{c}$ と $\gamma_{n}$ の関係を示す.

* $K_{n}=0.01$ の場合，振幅測定時の誤差率は最大の場合でも $2 \sin K_{n}=0.019$ ，すなわち $1.9 \%$ にすぎない。 


\section{3. 試作した測定装置とその特性}

\section{1 測定装置の試作}

上記の原理に基でいて表 1 に示与各種 の機器を䏔いて測定系を構成した。測定之 性能に重要な影響を与える磁気へッドは 工作機械の実稼動状態を考慮すると， ッドーテープ間隔 $\left(d_{R} C, d_{R P}\right)$ をかなり大 きくする必要があるので空隙長 $l$ の大き なものを選び，これに伴って蕌録一ッド では強磁界を形成できるように信号電流 容量の大きなものをけ作して用いた。

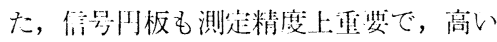
真円精度が装求される。本研究では表 1 に亦す寸法のアクリル樹脂製川板の外周 に一般計測用磁父テープをはり付けた簡 便なものを用いた．軸取付け後の総合的 真円度誤差は半径方向で士10〜15 $\mu \mathrm{m}$ であったが，以下の使用条件ではかなり 満足できた。また，軽量であるため被測 告系以与方分影響も無視できよう。

\section{2 測定性能の検討}

3.2 .1 基準信劣0)記録再生特性 磁気記録再生時の啫特性はすでによく

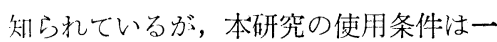
般に用いられてきたものとかなり異なる から，測定条件の選定も兼礼て，まず基 準信号の記録再生特性を検討した.

図 3 (a) は記録速度 $N_{R C}$ 岁変化し，一 定の速度 $N_{R P}$ で再生したときの記録波 長 $\lambda$ と再生出力との関係である。一般に 短波長信号ほど記録㧍よび再生性能は悪 化し，再生出力が減少与ることが知られ ている*が，本研究では空隙哀 $l=1 \mathrm{~mm}$ 0)目作記錄一ッドを用いたひで， $\lambda<2$ $\mathrm{mm}$ で藷しい再生出力の低下゙がみられ

た. …万力, 同時記録再生方式で注記録周波数 $f_{s}$ が一定 の下で主:軸速度 $N_{0}\left(=N_{R C}=N_{R P}\right)$ を変化すれい゙，同時 $に \lambda=2 \pi N_{0} R / f_{s}$ の関係から $\lambda$ も変化守るので, 図の破 線で示与ような特性をとると予想される。図 (b) は実測 した同時記録再生特性である. 用いたWFM の許容入力

* テープ分離損失 $=20 \log _{10} \mathrm{e}^{2 \pi d / \lambda}=54.6(d / \lambda)(\mathrm{dB})$, 空隙 長損失 $=20 \log _{10}[(\pi l / \lambda) / \sin (\pi l / \lambda)](\mathrm{dB})$ など入の減少に 伴って増加することが知られている5).
表 1 試作装置に用いた機器

\begin{tabular}{l|l}
\hline 基準信号発 & $\begin{array}{l}\text { 明石製作所 自動振動分析装置 (AVA-1) 内藏発振器 TAK-1 } \\
\text { 振器 }\end{array}$ \\
& 発振帯域: $0.5 \mathrm{~Hz} \sim 5 \mathrm{kHz}$, 出力: $0 \sim 10 \mathrm{~V}_{\mathrm{p}-\mathrm{p}}$, 内部抵抗: $1 \mathrm{k} \Omega$ \\
& 以下
\end{tabular}

記録増幅器 同上: AVA-1 内蔵加振器駆動アンプ MSB-52 T

出力: $0 \sim 100 \mathrm{VA}(0 \sim 3 \mathrm{~A})$, 入力インピーダンス: $100 \mathrm{k} \Omega$

記録一ッド $\mid$ 自作, ギャップ: $l_{1} \times w_{1}=1 \times 5(\mathrm{~mm})$, ギャップスペーサ: 黄銅, コア: 積層けい素鋼板, コイル巻数: 750

基準信号円 自作,アクリル樹脂円板（径 100 および $250 \mathrm{~mm}$, 厚さ $10 \mathrm{~mm}$ ) 板 の外周部に一般計測用磁気テープ（幅 $1 / 4^{\prime}$ ，厚さ $40 \mu \mathrm{m}$ ）を貼付

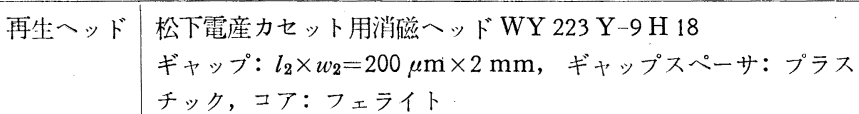

再牛増幅器 三栄測吠 直流アンプ $6 \mathrm{~L}$ 5-P, 入力範囲: $150 \mu \mathrm{V} \sim 30 \mathrm{~V}, 0 \sim 20$ $\mathrm{kHz}$ ，ゲイン: 0 300, 入出力インピーダン火: $10 \mathrm{M} \Omega / 10 \Omega$

ワウフラッ $\mid$ 目黑電波測器 MK-66 A, 中心周波数: $3 \mathrm{kHz} \pm 200 \mathrm{~Hz}$, 測定域:

タメータ $0 \sim 3 \%$, 入力レベル： $30 \mathrm{mV} \sim 30 \mathrm{~V}$ ， 入出力インピーダンス: $300 \mathrm{k} \Omega / 600 \Omega$

観測記録用 $\mid$ データレコーダ, シンクロスコープ, 電磁オシログラフなど

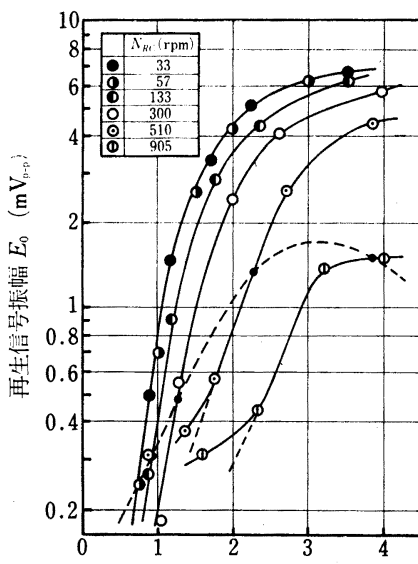

記録信号波長 $\lambda \cdot(\mathrm{mm})$

$I_{R C}=0.3 \mathrm{~A}_{\mathrm{rms}}, \quad d_{R C}=d_{R P}=200 \mu \mathrm{m}$, $N_{R P}=300 \mathrm{rpm}$

(a) 記録信号波舆の)影響

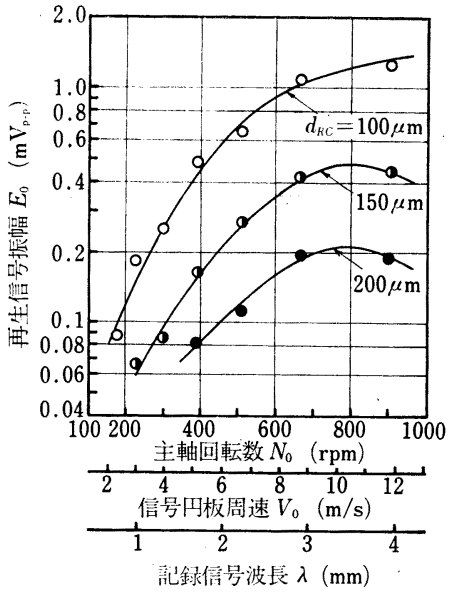

$d_{R P}=100 \mu \mathrm{m}, I_{R C}=0.3 \mathrm{~A}_{\mathrm{rms}}$, $f_{s}=3 \mathrm{kHz}$

(b) 问時記録再生:特性
図 3 磁父記録再生特性（1） 


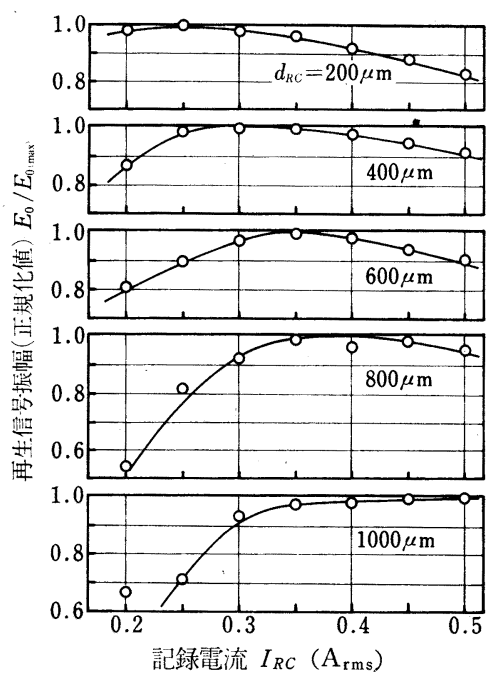

$N_{R C}=33 \mathrm{rpm}, N_{R P}=300 \mathrm{rpm}, f_{s}=50 \mathrm{~Hz}$

図 4 磁気記録再生特性 (2) 一一記録電流量 の影響

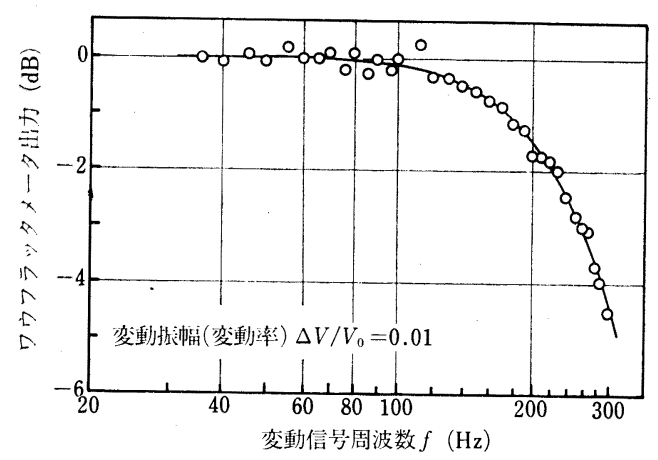

(a) 周波数応答特性:

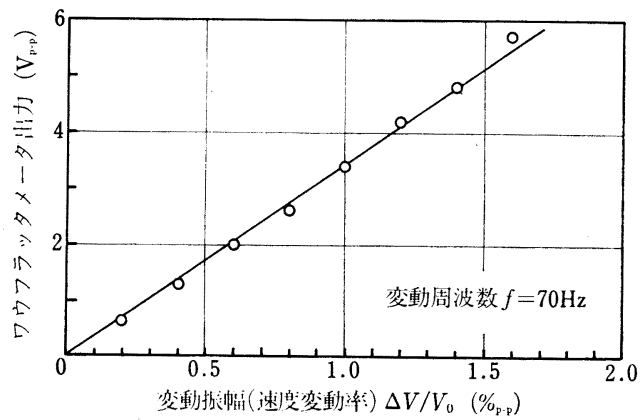

(b) 拻幅魚心答特性

$d_{R C}=d_{R P}=100 \mu \mathrm{m}, \quad I_{R C}=0.3 \mathrm{~A}_{\mathrm{rms}}, f_{\mathrm{s}}-3 \mathrm{kHz}$, $N_{0}=510 \mathrm{rpm}$

図 5 ねじり振動検出特性:

録性能を向上すれば，さらに低速の場合にも適用が可能 となろう・例えば, $l$ は一般に $d_{R C}$ と同程度に選ばれるこ とが多いが，現在より 1 オーダ短い $l=100 \sim 200 \mu \mathrm{m}$ ○)

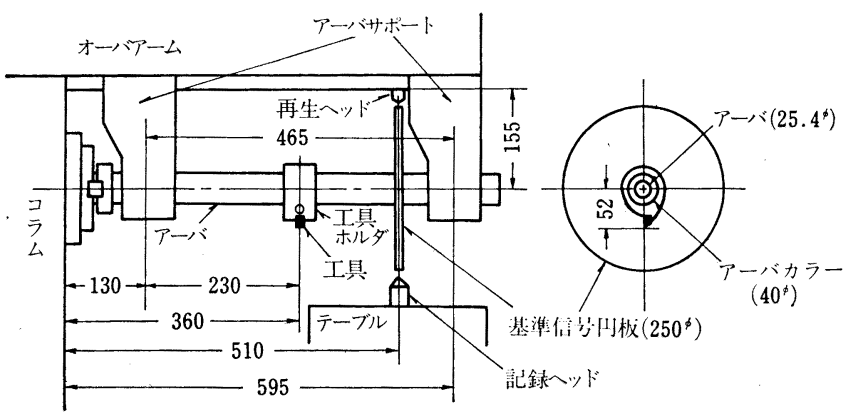

図 6 実験装置概要

記録ヘッドを用いれば，記録特性も1オーダ短い波長域 ヘ十分拡大できよう.

なお，図 3 (b) にみるように記録一ッドと記録面の間 隔 $d_{R C}$ が大となれば, 当然記録面での信号磁界強度が低 下する結果, 再生出力沙減少するので, $d_{R P}$ 上共に $d_{R C}$ は小とする方が有利である。しかし，図4 にみるように 記録信号電流量 $I_{R} C$ とも関連して记録磁界強度が過大と なった場合，ひずみの発生および聯化状態の特異性6)か

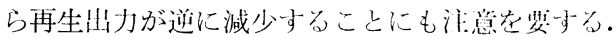

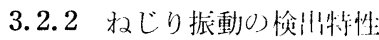

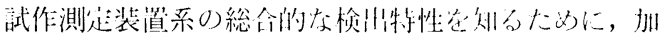

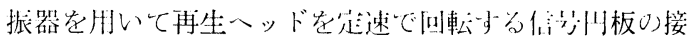
線方向に振動させ，相刘的に回䡆速度が怕速度を中心 に正弦波状に変動与る状態をシミュレートした。

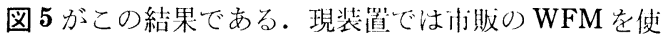
用しており，搬送周波数が $3 \mathrm{kHz}$ であることから周波数 応答帯域は $280 \mathrm{~Hz}(-3 \mathrm{~dB})$ である.こ机は従来の測定 法2)3に比べてかなり広いといえるが,さらに高周波の搬 送波を用いれば，より高域までの測定が可能であろう. 実験範囲では直線性も非常に良好であった。

\section{4. 横型フライス盤主軸の空転時回転むら}

工作機械主軸の稀じり振動の解明をすすめるにあた り, 試作装置の実用上の問題点を調べる意味も兼ねて, 横型フライス盤の空転时回転むら在測定してみた。

\section{1 供試フライス盤および実験条件}

咨験にはH立製作所)能フライス盤 $2 \mathrm{ML}$ 製老打い,

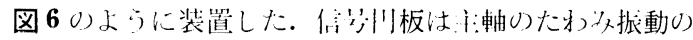

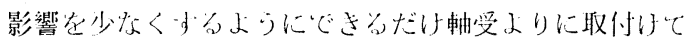
ある。また，再生一ッドと記錄一ッドU隔たり角 $\varphi$ は $180^{\circ}$ である。供試機は図 7 にみるように 33〜2 $000 \mathrm{rpm}$ の範囲で 16 段階に主軸速度を変換できるが，測定装置 の性能を考慮して，実験はこの内 133～905 rpm の8 速 について行った. 


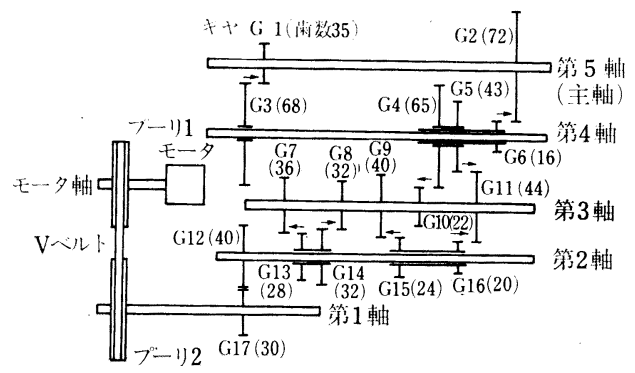

(a) 主軸駆動機構

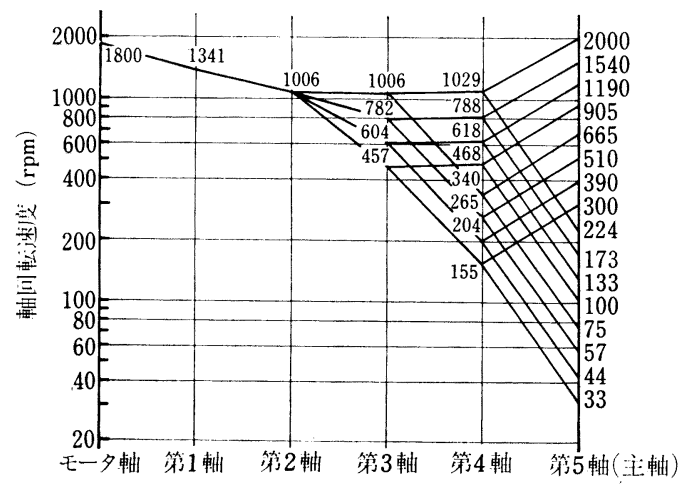

(b) 主軸速度線图

图 7 主軸速度の変換

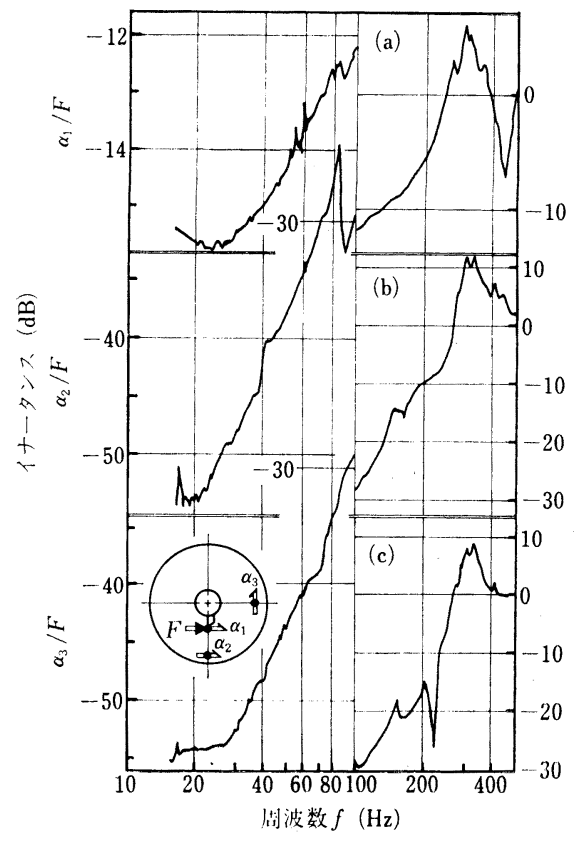

$F-3 \mathrm{~kg} \mathrm{wt}, 0 \mathrm{~dB}=1 \mathrm{G} / \mathrm{kg}$ wt

図 8 主軸系加振応答特性

図 8 は主軸系の加振応答特性の一例で, テーブルに固 企した加振器により筴験用工具の刃先位置へ水平方向の

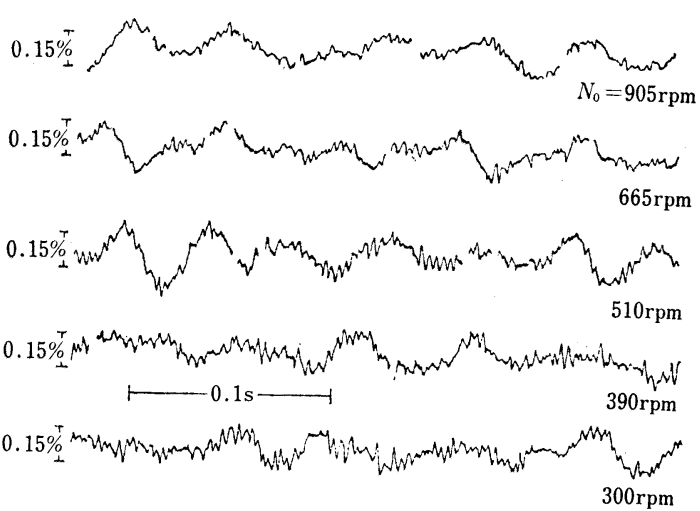

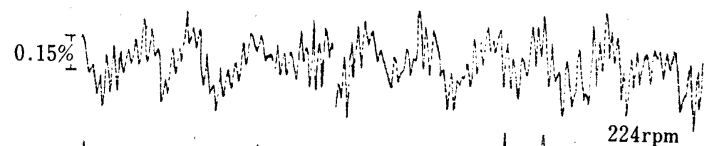

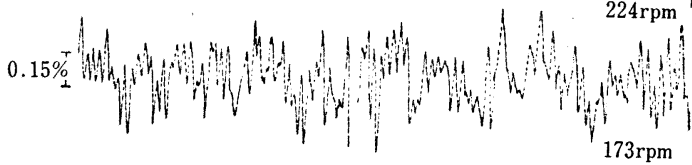

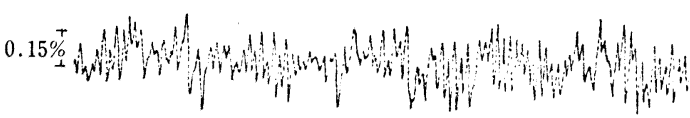

図9出力波形例

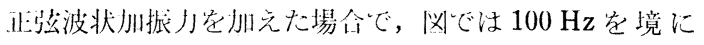
してスケールを变えて表示してある。（a）泇振点での 加振方向応答, (b), (c) は打のおの信号円板外周部の加 振方向と加振值㑇方向の応答である. (a), (b), (c)のいず れの場合にも現れる $300 \mathrm{~Hz}$ 付近のピークがこの軸系の 衫じり共振点を, また (c) の場合の夕消失する $80 \mathrm{~Hz}$ 付 近のピークがたわみ共振点であると推定される. その 他, 図には $20 \mathrm{~Hz}$ 付近にもピーク様のものが, いくつか 夕うけられるが, 加振器の容量不足から低周波数域の応 答は明確ではない。

\section{2 実験結果とその考察}

図9 は主軸回転数を変化した場合の各回転数での出力 波形の一例である。先に述べたように本波形をそのまま 速度変動波形として取扱うことに壮問題があるが，この 未補正データを用いて変動状態を推定することは可能で ある。供試機では第 5 軸（主軸）のギヤ 1 （汹 7 ）が作

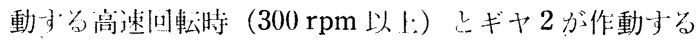

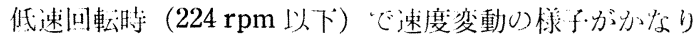
異なり，低速回転時には高畦波成分が著しく增加するこ となどを知り得る。図 10 は，乙れらのデータを周波数 分析した結果で，眓2 で述べた補正を施してある。100 $\mathrm{Hz}$ 以下では, 各回転数共 $20 \mathrm{~Hz}$ 付近を中心とする一, 二の優勢なピークがみられるほか, いくつかの周期性の 


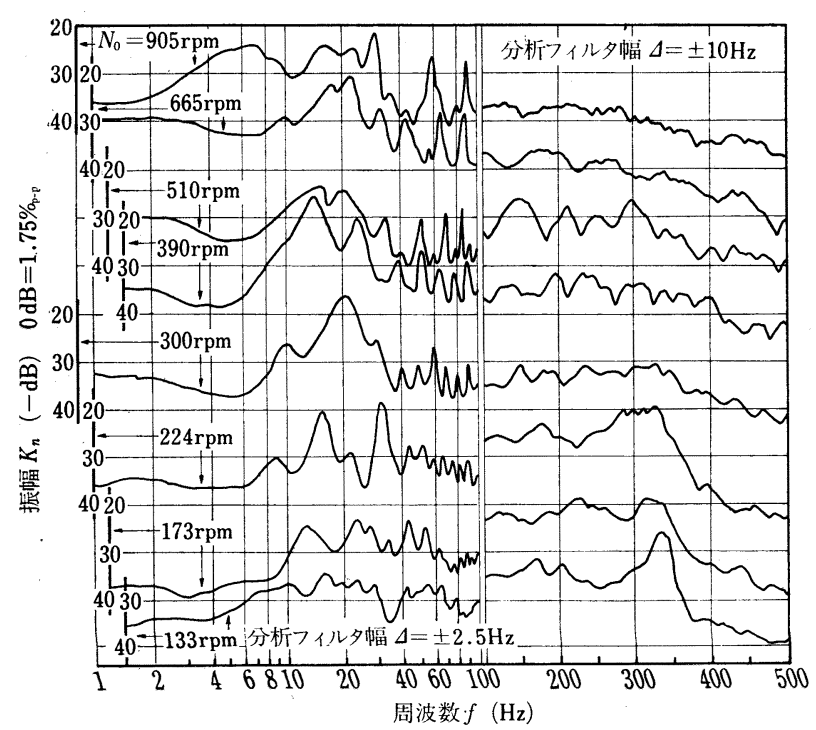

図10 周波数分析図

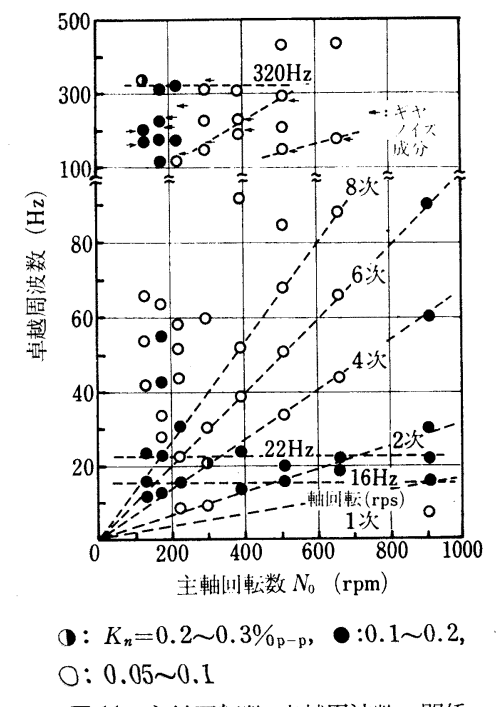

図 11 主軸回転数一卓越周波数の関係
あるピークがあらわれている。 また, $100 \mathrm{~Hz}$ 以上では高 速回転時のパターンが割合平たえで，かつパワーも低い のに対し，低速回転時には $300 \sim 350 \mathrm{~Hz}$ 付近に優勢なピ ークをもつことがわが。な打，ハターンが $300 \mathrm{~Hz}$ 付 近から全般に右下がりの傾向を亦しているいは，測等系 の周波数特性（脳 5 (a)) によるものである. 同一条件で の数回の測定データについて以上の分析を繰返し, 変動 率 $K_{n}=0.05 \% \mathrm{p}-\mathrm{p}$ 以上㧍よびピーク・デプス差 $5 \mathrm{~dB}$ 以 上のピークに注目して, 主軸回転数と卓越周波数の関係 を整理した．図11にこの結果を示す。この結果から供 試機の空転時回転むらは主に次の 4 つの成分から成って おり, 最も優勢な成分は $K_{n}=0.2 \sim 0.3 \% \mathrm{p}$ 程度であっ た。

（1）主軸回転数に比例する成分で，主軸の偏心，ふれ まわりなどに起因すると思われる，特に偶数次高調波成 分 $2 k n_{0}(\mathrm{~Hz})(k=1,2, \cdots \cdots)$ が顕著に現れるが，本実験で は $\varphi=180^{\circ}$ としたため $2 k n_{0}(\mathrm{~Hz})$ 付近で補正量が最大に

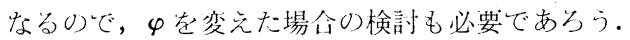

（2）各回転数に共通で，必最も優勢采 $20 \mathrm{~Hz}$ 付近 $(16 \sim 22 \mathrm{~Hz})$ の成分. 機械各部の単打撃テストにより推

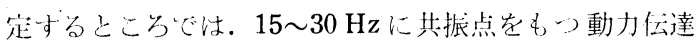
用 Vベルトのばたのきによる成分と思わ扎る。

(3) $224 \mathrm{rpm}$ 以下の低速回転時に顕著な $300 \sim 350 \mathrm{~Hz}$ の成分. 図 8 の結果から主軸の稀じり共振に基づく成分 と考えられる．低速時と高速時におけるこの成分の差異 には質量の大きなギヤ2(図7) の慣性効果が関係あろ う.

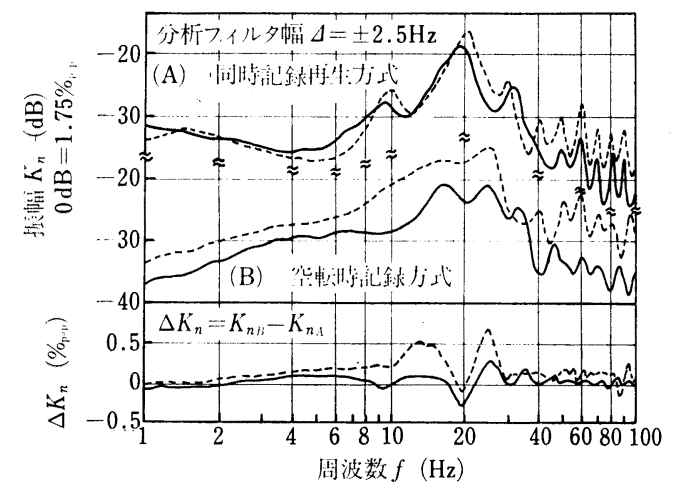

图 12 空転時記録方式と同時記録再生:方式の比較

（4）ギヤから発生するギヤノイズに起因する成分．図 中矢印で示すのは，種々の伝達ギヤが発すると考元ら れるギヤノイズ (歯数 $\left.\times n_{0}\right)$ の周波数で, 高周波域のピ 一クにはこれとほぼ一致するものが多くみられる。この

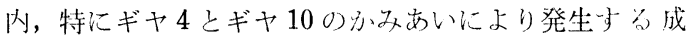
分注破線で示吉ように系統的に現水て揖り，この部分に 何らか0矢陷が予想され光。

なお，図 12 注同一条件におけ台独立した 2 回の実験 に対与るスペクトルの比較（奉線上破線）で，间時記録

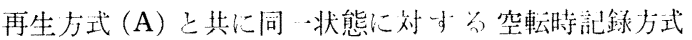
(B) による結果も小している。後者の再現性に問題があ るのに対して，前者のそれは良好で，このような微小変 動に対する同時記録再生方式の有效性を示している。 た，この例でみるように測定方式の違いによる測定值の 差異は大きいときで $0.5 \% \mathrm{p}$ - 程度であるから, 重切削 
時などのかなり大きな変動量の測定には空転時記録方式 も十分有効といえよう.

\section{5. 結 論}

工作機械了:軸系の称じり振動の実験的解析に役立てる 目的で，音響機器の问転むら测定に用いら机え市販のワ ウフラッタメータ老芯朋した測定手法老考察し，その特 性を検行与るとともに，その応用性を調べる意味も兼称 て，横型フライス盤主軸の空転時回転むらを測定した。 得られた絬果をまとめると次のようである。

（1）北作した測定システムは簡便で，かつ彷来の手法 に比較して周波数特性も良好 $(\sim 280 \mathrm{~Hz}:-3 \mathrm{~dB})$ で ある。同牌记銢再生方式によれば，変動率 $0.5 \% \mathrm{p}-\mathrm{p}$ 以下の変動も精度よく測定できるほか, 切削時に発 生するかなり大きな变動に刘しては空転時記録方式 でも十分有効と思われる。

（2）同時記録再生方式の場合，磁気記録再生特性上， 試作装置は軸速度 $133 \mathrm{rpm}$ 以上でしか使えないが， 磁父へッドの性能を向上することにより，乙の限界 を1オーダ下げることも十分可能である.

(3) 供試フライス盤主軸の空転時回転さらは最も優勢 な成分の変動率が $0.2 \sim 0.3 \% \mathrm{p}-\mathrm{p}$ で，大別して， (a) V ベルトのばたつき，(b) 軸ぶれ，(c) 軸の放 じり振動，(d) ギヤノイズの 4 つに基づく成分から なる．全回転数で（a）成分が最も優勢であるが，低 速時には (c) 成分も優勢となった.

終わりにあたり，本研究に協力された東啓二（松下電 工), 白国紀行 (国鉄), 秋山稔 (東大大学院) の諸君, および磁父一ッドの提供をうけた松下電器産業(株)に深 く感謝する. また, 本研究は炤和 49 年度科学研究補助金。 の援助をらけた。

\section{参 考文 献}

1) 例えば, B.I.C.R.A. ed.: A Handbook on Torsional Vibration, Cambridge U.P., (1958) 593-629.

2) 大野進一，荒井紀博：びびり振動中の回転数之振動数の 変動の測定, 日本機械学会講演論交集, 700-14 (1970) 69.

3）柳下福蔵, 石田健二郎：工作機械における主軸の回転速 度の変動について (第 1 報), 昭和 49 年度精機学会秋季 大会学術講演会前刷 (1974) 67 .

4）例えば，日本工業規格JIS-C 5521-1972（ホノモータ試 験法), JIS-C 5551-1971 (テープレコーダ試験法).

5）多田正信：磁気録音機，オーム社 (1965) 23.

6）岩崎俊一, 中村慶久: 磁気記録の基礎理論, 電子技術, 10, 12 (1968) 6 .

$\overline{\overline{\text { 情報 }}}$

\section{通産省・51 年度の無人化工場システム開発}

通産省は48 年度から 3 か年計画で検討してきた機械 工場無人化モデルの研究開発計画に基づき, 51 年度から 素形材加工部門を含めた無人化工場システムの開発を進 めることになった。

工場無人化の研究は機械工業における多品種少量生産 部門を対象として, 安全, 無公害, 人間性回復, 省資 源, 省エネルギなどの観点から取り上げたもので，この 成果については米国, 英国, 西独などの海外諸国からも 注月を集めて打り, 同省も今回の研究報告は多品種少量 生産のオートメーション化について問題提起をしたもの と高く評侀している。

そもそも工埸無人化モデルの作成は同省が機械技術協 会（会孯・杉本正雄氏）に開発を委託，同協会が総合委 員会（委員哀・竹中規雄氏=日本大学教授）と三つの実 行委員会を設けて検討を進めてきたものである。

機械工場無人化モデルの基本案件として与えられたの は, (1)生産形態, (2)多品種少量生産, (3)受注方式, (4) 機械工場の 4 点で，無人化工場の普及時期は 1980 年代 初めに開発，同年代中ごろから普及するとしている。

生産品目は産業機械などの要素となる主要機能部品を 生産する工場となっている。

開発するシステムは，(1) トータルシステム設計，(2)
在庫管理システム設計, (3) 製造ラインシステム設計, (4) 検査診断システム設計, (5) 工場管理システム設計となっ ているが，このほかにソフトウェアの体系化研究とシス テム研究，技術予測も検討対象となっている.

これまでの 3 か年 計画では 48 年度に無人化機械工場 モデルの基本設計， 49 年度に基本システム設計， 50 年 度に全体のとりまとめを中心としたシステム設計の研究 を行った．これに基づき 51 年度からは従来の研究が素 形材については外注を前提としていた点を改め，素形材 を含めて工場無人化システムの開発を進める．具体的に は自動車，建設機械などに組みこまれているギアボック スを無人化工場で製作するシステムを開発する。

開発委託先汢これまで同様，機械技術協会となる可能 性が強く，同省では，システム開発費として 1800 万円 を一般会計に計上している。 また同省では工場無人化モ デルは多品種少量生産という特性をもった機械工場のた めに開発されるが，このシステムが開発された場合，多 量生産システムへの影響は大きいとみている.

これは多品種少量生産システムにおける技術開発法直 接な形で多量生産にトランスフォさせることが可能であ るため, 機械工場の無人化は技術的にみて波及効果が大 きい. （服部 敏夫） 